Industrial Marketing Management, Volume 40, Issue 5, July 2011, Pages 671-682

\title{
ASSESSING VALUE-IN-USE: A CONCEPTUAL FRAMEWORK AND EXPLORATORY STUDY
}

\author{
Emma K. Macdonald (Author for correspondence) \\ Cranfield School of Management \\ Cranfield University \\ Bedfordshire, MK43-0AL, UNITED KINGDOM \\ emma.macdonald@cranfield.ac.uk,+44-(0)1234 751122
}

\author{
Hugh Wilson \\ Cranfield School of Management \\ hugh.wilson@cranfield.ac.uk, +44-(0)1234 751122
}

\section{Veronica Martinez}

Cranfield School of Management

v.martinez@cranfield.ac.uk,+44-(0)1234 751122

\section{Amir Toossi}

Cranfield School of Engineering

a.toossi@cranfield.ac.uk,+44-(0)1234 754749

\section{ACKNOWLEDGEMENTS:}

The authors gratefully acknowledge the funding and support of the EPSRC through the Cranfield Innovative Manufacturing Research Centre (IMRC). The authors also acknowledge with thanks Marko Bastl, Prof Steve Evans, Dr Rick Greenough, Dr Mark Johnson, Grace Liu, Dr Helen Lockett, the anonymous practitioner informants, and the editors and anonymous reviewers of this special issue. 


\section{BIO PAGE}

Dr Emma K. Macdonald is Senior Research Fellow in Marketing at Cranfield School of Management. She is also principal researcher for the Cranfield Customer Management Forum. Her research interests include customer value co-creation and customer experience. She has published in the Journal of Business Research and the Journal of Marketing Management.

Professor Hugh Wilson is Professor of Strategic Marketing at Cranfield School of Management and Director of the Cranfield Customer Management Forum. His research interests include customer experience, marketing and sustainability, and multichannel customer management. He has published over 30 academic papers in journals including Journal of the Academy of Marketing Science, Journal of Business Research and Industrial Marketing Management, amongst others.

Dr Veronica Martinez is Principal Research Fellow in the Centre for Business Performance. Her research interests revolve around the field of measuring and managing business performance, supply chain management and value creation in strategy management. She has published in International Journal of Operations and Production Management, amongst others, and is author of several industry reports.

Amir Toossi is a PhD student in the School of Engineering. His research interests include maintenance engineering and management, asset management services, and business partnerships and value co-creation. 


\section{RESEARCH HIGHLIGHTS}

- We propose a new framework for assessing customer value of solutions.

- Current service quality measures assume that value is embedded in service delivery.

- Buying group members assess the quality of their own organization's usage processes.

- Buying group members articulate value-in-use at organizational and individual levels.

- Value-in-use changes over time impacting solution selling and innovation. 


\section{ABSTRACT}

Developing approaches for understanding customer perceived value is a priority for managers and scholars alike. A conceptual framework for assessment of value-in-use is proposed and explored within the context of a maintenance service provider. In contrast to value models in previous empirical research, the framework includes assessment not just of provider attributes but also of the customer's usage processes, as well as customer evaluations of the value-in-use they obtain. Interviews with members of a cross-disciplinary buying group provide support for the framework, including the observations that individuals can assess the quality of their usage processes and that they can articulate value-in-use at both organizational and individual levels; the further concept of network quality also emerges from the data. Assessment of usage process quality as well as service quality evolves as the customer's goals evolve. Practitioners may wish to elicit usage process quality and value-in-use as well as service quality. Research directions include scale development for both usage process quality and value-in-use.

\section{KEYWORDS}

buying group; customer perceived value; service-dominant logic; service quality; usage process; value-in-use 


\section{ASSESSING VALUE-IN-USE:}

\section{A CONCEPTUAL FRAMEWORK AND EXPLORATORY STUDY}

\section{Introduction}

A recent review highlighted that a key research priority for managers and academics alike is "creating and enhancing tools for capturing value in use for services and communicating value to customers” (Ostrom et al., 2010: 26). Understanding what customers value has long been a challenge: "gaining a comprehensive understanding of the value of a market offering in a particular customer setting may appear monumentally difficult" (Anderson \& Narus, 1998: 55). In discussions of value, there has been an increasing recognition (e.g. Moller, 2006; Vargo \& Lusch, 2004, 2008a) of the importance of value created through the customer's own processes and/or jointly created between the customer and supplier. Moller (2006) observed that, until recently, the perceived value literature has been largely silent about joint value creation requiring the combined activities of the buyer and the seller. This share of voice has, however, been only relative (Normann \& Ramirez, 1993; Dorsch, Swanson \& Kelley,2001), and in recent years, Vargo and Lusch's (2004) service-dominant logic (SDL) along with the work other scholars (Woodruff \& Flint, 2006; Payne, Storbacka \& Frow, 2008; Prahalad \& Ramaswamy, 2004) have reminded marketers that the customer is always a co-creator of value who co-creates value 'in use', as opposed to value being embedded in tangible goods at the factory gate.

Value has several meanings in the management literature, with a frequent focus on profit at the expense of other possible contributions to value that relationships can make (Walter, Ritter \& Gemunden, 2001). While Walter et al. (2001) point out that understanding value creation from a provider's perspective is important, other work has examined the customer's perspective (Woodruff and Gardial, 1996). For example, the value-added concept allows sellers to think of bundles of 
attributes and seller-controlled variables (Woodruff \& Flint, 2006). While SDL literature has highlighted the significance of customer perceived value-in-use (or value-in-context, as per Vargo, Maglio \& Akaka, 2008), this strand of scholarship has as yet neither defined this term nor proposed how it can be assessed. Building on Vargo and Lusch (2004, 2008a) as well as Woodruff (1997) and Woodruff and Flint (2007), we define value-in-use as a customer's outcome, purpose or objective that is achieved through service. We adopt in turn Vargo and Lusch's (2004, 2008a) definition of service as the provider's process of using its resources for the benefit of the customer. ${ }^{1}$ We propose that value-in-use provides a missing link between service quality on the one hand and relationship outcomes on the other. Consistent with the SDL argument, we argue that a value-in-use perspective is superior to the embedded value perspective which, building on the same authors, may be defined as: the presence of service attributes, and performances against those attributes, for which the customer is prepared to pay.

Discussions of value are perhaps particularly prominent in discourse on business-to-business contexts. As ‘servitization' (Vandermerwe \& Rada, 1988) pervades manufacturing, providers are challenged to assess the perceived value that 'integrated solutions' deliver (Jacob \& Ulaga, 2008). Solutions are defined by Evanschitzky, Wangenheim and Woisetschläger (2011, this issue) as “individualized offers for complex customer problems that are interactively designed and whose components offer an integrative added value by combining products and/or services so that the value is more than the sum of the components." If some felt that value propositions delivered purely through the appliance of physical goods could be assessed at the factory gate according to the goods-dominant logic of embedded value (Vargo \& Lusch, 2004), the notion of a solution

\footnotetext{
${ }^{1}$ We note that these definitions do not imply that the 'use' of 'value-in-use' is necessarily a customer's usage process subsequent to service (that is, processes making use of jus usus fructus, the right to appropriate the returns arising from exploiting the provider's resources, as Haase and Kleinaltenkamp (2011) delineate it in their application of new institutional economics to service-dominant logic). Rather, it may equally refer to the resource integration process through which the customer integrates supplier resources with customer resources or others available to the customer in the context of the customer's goals, thereby utilising the customer's right of jus usus, the right simply to use the provider's resources. Hence the proposal by Vargo, Maglio and Akaka (2008) to adopt instead the term 'value-incontext'. With this clarification, we believe the terms are interchangeable.
} 
clarifies the need to assess value that arises in the customer's space and through the customer's usage processes (Baines et al., 2007). Yet it is an assessment required by increasing numbers of manufacturers who may previously have given it little thought; for fifty-eight percent of US manufacturers, tangible goods now form only part of the value proposition, and this hybrid approach is growing across other developed nations, though its impact on profits is mixed (Neely, 2008). Marketing discourse increasingly therefore focuses on utilization (Gummesson, 1995; Lindgreen \& Wynstra, 2005; Ngo \& O’Cass, 2009).

While Vargo and Lusch (2008a) position their contribution as a positive rather than a normative one, their highlighting, along with other scholars, of the customer's contribution as a co-creator of value suggests that a shift is required in how organizations elicit value sought by and derived by customers in their customer insight processes (Vargo \& Lusch, 2006). In this paper, we ask the question: How does a business customer assess value-in-use? Combining means-end theory (Woodruff, 1997), work on co-creation (Payne et al., 2008), and definitional work on value (Vargo \& Lusch, 2004; Woodruff \& Flint, 2006), we propose a conceptual framework which relates service quality, usage process quality, and value-in-use. We explore this framework in a factory maintenance context to ask how customers assess the value-in-use arising from a provider's service at inception and as the relationship continues over time. We adopt a critical realist perspective which allows the use of causal language and is "particularly well-suited as a companion to case research" (Easton 2010: 119). Epistemologically, this perspective justifies the use of a single case provided the process involves thoughtful in-depth research with the objective of understanding why things are as they are. The single-case analysis presented in this paper identifies the key mechanisms for customer assessment of value in a business-to-business context and over time. The findings provide some initial validation and refinement of our proposed framework for value-in-use assessment. 
Specifically, we make contributions in four respects. First, we argue that current service quality measures are insufficient for understanding customer value, because to use them in isolation as drivers of relationship outcomes would be to assume that value is embedded at the moment of service delivery, which following Vargo \& Lusch (2004) we argue to be incorrect. Second, we demonstrate that the customer can articulate both the constructs by which they assess value-in-use and the causal chain by which they perceive value-in-use to be related to service quality. Third, we demonstrate that customers can also articulate usage process quality and how it contributes to valuein-use. Fourth, we explore how perceptions of value evolve in the B2B space, tentatively proposing that the value-in-use sought tends to shift from preventative goals to promotional goals as the former are satisfied. We conclude by suggesting implications for practitioners' customer insight processes, and proposing some research directions.

\section{Approaches to the assessment of customer perceived value}

Although the potential of value-in-use for understanding the customer's world is widely recognised conceptually (Flint \& Mentzer 2006; Vargo \& Lusch 2004; 2008a; Vargo, Lusch \& Morgan, 2006; Woodruff, 1997), it is still "in its research infancy" (Ostrom et al., 2010: 26). It is not yet clear how to operationalize it or relate it to the perceived excellence or superiority, to use Zeithaml's (1988) definition of quality, of a provider's value proposition. In working towards this goal we will start by considering existing measures of quality.

The original manufacturing management conceptions of quality were relatively straightforward (Ulaga, 2003). Quality was seen as a comparison of customer perceptions of tangible goods attributes against expectations, and was regarded as signalled through marketing communications (Zeithaml, 1988; Kirmani \& Rao, 2000). For value propositions not delivered exclusively through the appliance of tangible goods, SERVQUAL and its variants took a similar stance of measuring 
conformance to customer expectations (Zeithaml, Berry \& Parasuraman, 1996). This generation of service quality research broke new ground in acknowledging that this judgement of excellence or superiority was ultimately perceptual rather than objective, but shared with earlier quality work the emphasis on the moment of interaction between customer and provider (Parasuraman, Zeithaml \& Berry, 1988). Just as Vargo and Lusch (2004) argued that value is not created at the factory gate, the service quality literature stream has been criticised for not focusing on the outcomes of a service encounter (Buttle, 1996); that is, service quality does not assess value-in-use as we have defined it. In particular, it ignores customer processes which may contribute to value co-creation, such as: (a) usage processes (Vargo \& Lusch, 2004) which may occur subsequent to the provider's delivery process, as in the case of learning on an MBA program being applied in a student's subsequent career; (b) experience co-creation by the customer (Payne et al., 2008; Lusch, Vargo \& O'Brien, 2007); and (c) the contribution to value creation of other customers (Diamond, Sherry, Muniz, McGrath, Kozinets \& Borghini, 2009) and other resource providers (McColl-Kennedy, Vargo, Dagger \& Sweeney, 2009). Partly because of these limitations, SERVQUAL has been modified in some sectors, such as information systems (Kettinger and Lee, 1994).

A further critique of service quality research has taken a relationship perspective. For instance, the American Society for Quality (ASQ, previously ASQC) shifted from defining quality as "the totality of features and characteristics of a product or service that bear on its ability to satisfy stated or implied needs" (ANSI/ASQC, 1987) to a relationally focused, processual definition as "the ongoing process of building and sustaining relationships by assessing, anticipating, and fulfilling stated and implied needs" (Judd, 1994). Several studies have shown that customers can and do make judgements about the quality of their relationships with suppliers (e.g. Ballantyne \& Varey, 2006a; Storbacka, Strandvik \& Gronroos, 1994; Ulaga \& Eggert, 2006). Tuli, Kohli and Bharadwaj (2007) found that while providers tended to take a goods-centric view of customer solutions, defining a customer solution as a customized and integrated combination of goods and services for 
meeting a customer's business needs, customers took a relational process view of solutions, emphasising requirements definition and post-deployment support - both of which pertain to the customer's usage processes as well as the service directly provided by the provider.

In summary, while these critiques do not invalidate service quality as a useful measure of the supplier's contribution to value creation, a more holistic assessment of value-in-use would need to consider also: i) The role of the customer's usage process in value creation; ii) The extent to which the customer's intended outcomes are achieved - that is, the customer's value-in-use; and iii) The role of the supplier-customer relationship in defining what the supplier's contribution is to be, including the supplier's support for the customer's own usage processes. We next synthesise this argument into a framework for assessing value-in-use.

\section{A means-ends framework for assessing value-in-use}

Figure 1 shows our conceptual framework for value-in-use assessment, which builds on Woodruff's customer value hierarchy perspective (1997).

Place Figure 1 Here

Vargo and Lusch's (2004) call to view tangible goods as 'appliances' for service delivery has been echoed in the co-creation work of Payne et al. (2008) who reiterate that service should be viewed as a flexible process, not the provision of static entities. This notion - in combination with our definition of value-in-use earlier - implies that customers' use of a provider's service is goaldirected. In a review of customer behavior, Bagozzi (1997) observed that the transaction-related 
processes of buying and selling are goal-directed behaviors. However, recent work brings to the fore the importance of usage (Moller, 2006; Vargo and Lusch, 2004). We consider the usage process as a purposeful, goal-directed behavior which, like service quality and relationship quality, is susceptible to the customer's quality assessment.

Woodruff articulated the means-end approach for capturing an understanding of customer value (Woodruff, 1997; Woodruff \& Gardial, 1996). Means-end laddering theory (e.g. Kelly, 1963; Gutman, 1982) suggests that individuals, both as consumers and as members of a buying center, have networks of goals comprising multiple levels. Individuals have goals regarding their own actions and goals regarding the outcomes of their actions (Gutman, 1997). Consistent with their ladders of goals, individuals view provider offerings from different perspectives across a hierarchy of goals (Peterman, 1997; Rugg, Mahmood, Rehman, Andrews \& Davies,2002). While originally developed for understanding consumer behaviour, means-end theory has been used for explaining behaviour of managers in customer value creation (Guenzi \& Troilo, 2006) and sales process management (Deeter-Schmelz, Kennedy \& Goebel, 2002). We are not the first to have observed that the value perceived by B2B customers has multiple levels (for example, Rugg et al., 2002; van der Haar, Kemp \& Omta, 2001). Both Guenzi and Troilo (2006) and Rugg et al. (2002) in a business context find that customers hold multiple levels of knowledge across the following range of goals, which can be thought of as going up a value hierarchy: (a) beliefs that relate to provider attributes or features; (b) subjective benefits; and (c) consistencies with personal values. The customer relates these levels with a mental map hypothesising causal links between these goals. In a B2B context goals may be individual or organisational. Customers may move back and forth between these in either direction, so an IT solution may be viewed as making me more efficient at my job (individual), helping my organisation maintain its competitive advantage (organisational), and increasing my job security (individual) (Rugg et al., 2002). 
Goal theory suggests a plausible explanation for the gap in understanding of value between customers and providers of 'solutions' (Paulssen \& Bagozzi, 2006): namely, that providers fail to recognise the importance of customer value perceptions at multiple levels and, particularly, the importance of higher level customer goals (Rugg et al., 2002). A plausible reading of Tuli et al.'s (2007) data is that providers' assessment of value tends to be attribute centric, focusing at the lower end of the hierarchy, whether because of a goods-dominant logic assumption that value creation occurs at the factory gate, or because this level is easier to measure. Importantly, we have argued that the notion of service quality is often equally obsessed with what the provider delivers, as opposed to the value the customer gets. Insufficient effort has been put into specifying how customers select and strive for goals (Bagozzi, 1997; Botschen, Thelen \& Pieters, 1999). We suggest, therefore, that in order to effectively elicit a customer's assessment of value-in-use, customer perceptions need to be measured up as well as down the hierarchy of customer goals.

The implication of goal theory for value assessment is that providers cannot assume that customers' value assessments are made at a single level, nor with regards purely to provider attributes or features (Locke \& Latham, 2002). Providers must also allow for assessments made at multiple levels and at increasing levels of the value hierarchy including at the level of subjective benefits.

Our framework takes direction from these hierarchical goal perspectives. Customers evaluate both service quality and value-in-use: indeed, their goal hierarchy includes a mental model as to how these levels relate. The customer is prepared to pay for the presence of certain attributes not because they exceed expectations (Zeithaml et al., 1996) but because of their association with higher goals in the customer's mental model.

Precisely the same reasoning applies to usage processes. If the customer co-creates value through interaction with the provider and other customers, then we would expect the customer's mental 
model to include these usage processes, and their hypothesised relationship to value-in-use in the goal hierarchy. The customer's evaluation of the usage process could be expected to possess a valence or direction in the same way as the customer's evaluation of the provider's service. That is, usage process quality exists and furthermore, there would appear to be no theoretical reason why it cannot be empirically elucidated.

The final element of our framework is relationship quality (Crosby, Evans \& Cowles, 1990; Dorsch, Swanson \& Kelley, 1998). We conceptualize relationship, following Morgan and Hunt (1994), as an ongoing process of interaction involving one or more value exchanges. In the light of Vargo and Lusch's (2004) conceptualization of value exchanges, we can hence see relationship as an interorganizational capability (Trist, 1983) by which exchange partners identify value-in-use sought, construct a value proposition, and assess service quality and value-in-use achieved; and relationship quality is the perceived excellence or superiority of this capability. Our conceptualization is consistent with that of ASQC which we discussed earlier, but adds clarity in the conceptualization of needs as the value-in-use sought.

We note that the framework does not assume that value-in-use sought by the customer remains constant through the relationship; this would be inconsistent with the phenomenological definitions of quality and value-in-use. The customer's assessment of value-in-use forms a cognitive map which may evolve over time (Huff, 1990). Equally, we do not assume that members of a buying group will share the same cognitive map.

Despite the array of techniques available for assessing the quality of supplier controlled processes, our empirical research (reported below) is consistent with the pressing practitioner need for more holistic customer insight measures (Ostrom et al., 2010). The goods-dominant perspective is inadequate for explaining the role of customers in deploying their own resources in creative ways to 
derive value-in-use from a provider's service that varies from that intended by the firm (Arnould, Price \& Malshe, 2006) and it is not consistent with an increasing shift towards a continuous-process perspective where the customer's role as co-creator is recognised (Vargo \& Lusch, 2004, 2006).

\section{Method}

Our conceptual framework (Figure 1) conjectures that business customers possess and can articulate a mental model relating provider-controlled attributes and their own use processes to value-in-use. We explore this framework through an interview-based case study in a maintenance context.

\subsection{Case selection}

Industrial maintenance is a context in which some emerging practices subvert traditional models of ownership and exchange (Tukker \& Tischner, 2006). In this environment, customers struggle with assessment of value in propositions such as Rolls Royce's 'Power by the hour' which sees them yielding power, control and expertise to the provider while simultaneously achieving greater organizational efficiencies (Baines et al., 2007). In this case the provider, traditionally a manufacturer of factory equipment, had recently shifted to providing an 'outsourced maintenance service' (OMS) for manufacturing plants. This proposition involves a fully managed maintenance program including provision of factory equipment, parts procurement/repairs, and third-party supplier management, administered by a service professional (SP) located full-time at the customer site. $^{2}$ As well as employing the on-site SP, the provider takes on some risk through a business

\footnotetext{
2 The outsourced maintenance program allows the provider to push their own-branded tangible goods but has a proportionally greater emphasis on procurement and management of third party services from multiple suppliers.
} 
model which takes a preventative approach to maintenance and assures the customer of savings. The proposition is unusual in its comprehensiveness and in the level of partnership it embodies which, at least in the selling stages, is offered and sold at a very senior level within the customer organization.

The selected customer organisation was the first company to purchase this innovative offering and its managers were well placed to reflect on any evolution of value over time from its four years of experience with it. For this organization, an engine manufacturer, maintenance is an essential but non-core function that ensures factory production lines continue running productively.

\subsection{Data collection}

A goal hierarchy is a form of cognitive map (Huff, 1990). To understand corporate decision making it is necessary to explore these maps for multiple individuals (Langfield-Smith, 1992; Larson \& Christensen, 1993) and across multiple functions including decision makers and users (Qualls \& Rosa, 1995; Johnston, Leach \& Liu, 1999). An initial interview with a key decision-maker defined the buying group, which was confirmed by interviewees subsequently. This buying group comprised four key decision-makers - operations manager, maintenance manager, factory manager and commercial manager - and four users (representing a subset of the total OMS user pool). The research protocol allowed for exploration to establish (a) what the customer believed the provider intended as their value proposition, (b) the process of provider selection and assessment, (c) the customer's assessment of value over time, and (d) what performance measures were used to assess providers. 
At three stages during the research, input was sought from managers in the provider to discuss the researchers' emerging understanding. Interim findings were presented to representatives of the provider's sales team and implications for the provider's value proposition were discussed.

\subsection{Data analysis}

Data was collected to explore the proposed framework (Figure 1). An analytical reflection of the transcribed interviews was carried out through the identification of patterns (Cassel \& Symon, 1990). The key themes in the a priori framework related to service quality, relationship quality, usage process quality, peer-to-peer interaction quality, and value-in-use. The coding process allowed for the emergence of additional themes: this occurred for 'network quality', further described below. One proposed theme - peer-to-peer interaction quality - attracted no data and was disbanded suggesting that it was not significant in the goal hierarchy for this customer. The majority of the data was coded by one researcher with 'member checks' (Woodside, 2010) conducted by a second researcher.

It became apparent that all interviewees perceived two time periods with distinct value perceptions: an early "introduction" period and a recent "current" period. The early period (referred to as Year 1 below) roughly corresponds with introduction up to month 12 of the customer's usage of the offering, while the later period (labelled Year 4) corresponds roughly with months 37 to 48 . The two time periods appeared linked in the minds of interviewees with the on-site SP involved: 'Year 1 ' corresponds with the term of the inaugural on-site SP who had since moved on, while 'Year 4' corresponds with his replacement. Hence, data was synthesised across the buying group for Year 1 (Table 1) and Year 4 (Table 2) and then summarised against the value-in-use framework. By 
synthesising across the buying group for simplicity, granularity may be lost with respect to differences in perceptions across the buying group; we offer this point as a topic for future research.

\section{Case study description}

We now provide an exposition of the case study data, including background for judging boundary conditions (Beverland \& Lindgreen, 2010; Stake, 1995), to tell the story of the OMS and its value assessment at Year 1 (Figure 2) and Year 4 (Figure 3).

\subsection{The introduction of the outsourced maintenance offering}

The customer has a long heritage in manufacturing industrial engines. Five years ago, managers investigated outsourcing of the maintenance function, essential for keeping production lines going, but which at the time seemed highly unstructured: "challenging," "awful" and "dreadful." However, managers had struggled for several years with how to improve it. It had in turn "been centralized, decentralized. It was pretty grim." Breakdowns were common with some machine lines achieving only $35 \%$ overall equipment effectiveness (OEE) - "and that's just outrageous." Maintenance was "in excess of $90 \%$ reactive", yet staff thought they were doing an effective job because they were good at "fire fighting."

Managers were concerned with the amount of time spent reacting and the lack of planning: "nobody ever sat back and thought about how you do this." Supervisors were spending time finding suppliers, obtaining quotations and chasing parts, and little time on "the preventative stuff, the visionary stuff, trying to do the planning, the preparation and delivering projects." 
After considering several providers, the customer engaged the case study provider to give a more proactive approach to maintenance. The provider was the only one that offered to place a permanent SP on-site. The provider would source, supply and repair third party equipment as well as its own branded equipment. Additionally, the provider's size and global reach meant it would bring a "full size inventory" of parts and "market clout" to purchasing.

Once the program was in place, it highlighted problems elsewhere. Notably, managers found that factory stores were disorganised and inefficient: "It was like a scrap yard and so we were throwing good stuff away because we didn't know that it worked." The problem was compounded by the existence of individual "squirrel stores" so, for example, after waiting for a part for one week " $a$ guy would come in from holiday and say, oh, I've got twenty of those in my cupboard." The provider was hence asked to add stores management to its maintenance responsibilities.

\subsection{Immediate impacts}

The customer found that the offering was being used more than expected and the impact was visible. Repairs were taking only ten minutes of factory supervisors' time, it was recalled, instead of days. "It suddenly freed up all the guys and it was great, that enabled us to then start talking about the things that we should be doing upstream to get TPM [Total Preventative Maintenance] sorted." Stores management was also positively perceived. Once the provider had bar-coded all items in the stores, the improvement was "fantastic": "We found something like 1.2 million dollars worth of obsolete stock that was just rubbish - in cupboards, under desks."

\subsection{The customer's role in co-creating value}


The customer organization was perceived as contributing to improved performance on-site through the introduction of new processes and training. Staff were trained in the use of more proactive maintenance processes and in the use of the now provider-run stores. The success of the new approach was perceived as being due also to the customer organization taking responsibility for improvements. For instance, one manager described a conversation where one of his factory supervisors was "demotivated" because he needed $\$ 140,000$ in spare parts to make his section perform better. The manager approved the bulk purchase under the following conditions: "Here's the deal, I will buy you this stuff, I expect you to look after it, maintain it, get it in the stores, label it." The result was that the area, previously running at 35\% OEE, was now "a hell of a machine tool line, it's now doing 85\% OEE - every day currently, every single day."

A key component in this initial success was thought to be the close working with the provider's SP: "I didn't treat him as a service provider, I treated him as one of my team. He sat in the same office with my first line. Every day he spoke to them. If there was a problem I would go and talk to him. He came to our team meetings." The closeness of these individuals continued despite the SP and managers moving onto different roles more recently. In more recent times, some managers questioned their organization's role in monitoring the OMS: "We have become a little bit complacent ... the KPIs aren't as good or robust as they should be...we have perhaps let this die a little bit and that worries me a bit."

\subsection{Importance of the individual service provider}

The contrast between the service provided by the original SP and his subsequent replacement highlighted the importance of this appointment. The original SP seemed to work very well with managers and developed a good relationship with factory floor supervisors: "One of the benefits that became obvious to us, we had a great guy doing the job." He was widely respected for being 
"on the ball with most things". Several comments were made, though, by both decision makers and users about the contrast in service quality since the original SP had shifted to a more senior position. The replacement SP appeared less responsive and less knowledgeable (contrast the quotes in Table 1 with Table 2).

\subsection{Assessing the value of outsourced maintenance}

A comparison of value-in-use identified in Year 1 (Figure 2) and Year 4 (Figure 3) highlights that efficiency, asset maximisation, asset control and time for core business were explicitly stated for Year 1 but not Year 4 although these presumably would have continued to be germane. Most likely, the customer felt that these value-in-use dimensions were already being achieved. There is some support for this explanation in the observation that despite the concerns raised by several study participants, the solution was renewed into a fifth year.

Managers believed that by Year 4, they had "turned around" maintenance. However, following the initial significant improvement, managers observed that it was difficult to quantify the incremental value from the continuing cost of the OMS. One commented that: "generally, it's a system that's bubbling along at a level that I just don't see anymore." The provider seemed to be finding it harder now to demonstrate value. Several changes in key personnel had compounded this difficulty including: (a) senior customer managers moving into different roles; (b) as noted earlier, the original SP had been promoted away; and (c) the current SP was no longer co-located with the customer's management team but sat in his own space on site, which meant that he - and consequently other provider managers - risked being disconnected from the everyday concerns of the customer's business. 
The standard by which the provider was assessed seemed to have shifted upwards. One manager reported that the provider was "good at the mundane, rudimentary, tick-over stuff but not good at innovation." There was also a concern that having become established, the provider had "relaxed" and lost "passion." This comment from another manager (previously a champion of the outsourced service) reflected the current view of the provider: "Do I see them as such a valued asset? Probably not at the moment. I still see them as providing us with a good service, but probably the focus has gone a little bit away. I believe that [the provider] now probably have taken it that it's a given thing that they'll be on site here, probably the emphasis has gone away from providing such a quality service to be honest."

Relationship quality assessments featured significantly in the Year 4 evaluations of the provider. Communication was a key issue, with complaints that the provider should be more explicit about their impact through reporting (see Table 2). The Year 4 picture indicated some mistrust about the commitment of the provider to meeting the customer's needs. The current relationship was described as "OK, but not great." There are multiple potential explanations for why relationship quality was assessed so differently and poorly at this later stage, for instance: (a) the replacement of the original SP with a different individual between Year 1 and Year 4, (b) the second SP appeared not to have tried as hard to embed himself at both senior management and operational levels of the customer organisation, (c) but even if he been successful in achieving the same level of embeddedness, perhaps differences in personal style - or even a personality clash - could have created similar deterioration in perceived relationship quality over time. The data are not conclusive on this point.

In both time periods, the customer's usage process quality was reflected upon, with a recognition that the customer needed to do its part in extracting value. Greater degrees of scrutiny were applied to internal processes within the customer organisation in Year 4 than in Year 1 with 
assessments tending towards the negative (Figure 2 versus Figure 1). While agreeing that usage process quality had deteriorated, there were differences in the explanations that were offered. For instance, one manager observed that his organization had weaknesses in providing information to the provider that was useful to their processes, such as production forecasting (which might point to weaknesses in outsourcing capabilities). Several managers and floor supervisors believed there was a lack of regular analysis (see Table 2).

In terms of overall value assessment, while outsourced maintenance had helped to streamline processes, it had not been without sacrifice, notably a perceived loss of knowledge and expertise within the customer organization (see Table 2). Also, communication was less direct and: "less efficient somehow - the number of people that we're having to speak to, the communication channels are longer. Inevitably you get Chinese whispers."

It seemed, then, that the value sought by the customer changed with time. Broadly, respondents recalled an initial quality assessment from what the provider's sales manager referred to as the "honeymoon" period, as summarised in Figure 2 and Table 1, and articulated a contemporaneous quality assessment in the later period of the engagement, summarised in Figure 3 and Table 2. The provider was perceived as having done well in satisfying the initial goals, but not so well in noticing the customer's additional goals over time: “They are not hungry enough. They should kick down the door and dazzle me. Am I unreasonable? No, I am demanding." The assessment of provider processes, customer usage process and value-in-use was on the whole more negative in Year 4. While value-in-use in Year 1 was assessed at both organization and individual levels, it was assessed solely at an organizational level in Year 4, possibly as a result of interviewees rationalising their complaints. 


\subsection{Provider response}

As a result of this research the provider implemented changes to re-establish intimacy with the customer. The onsite SP was encouraged to "get out of his office more" and his role was supplemented with a technical analyst to work closely with the customer management team.

The impact of the OMS on the customer's business following initial implementation had been dramatic. However, later when the effects were less evident, additional reporting was called for. Not realising this, the provider admitted "throwing" resources into relationship building activities in Year 1 and then "took a step back from it in Year 2." Resulting from this study the provider determined that in future greater attention should be given to reinforcing the value delivered at each period of time in acknowledgement that perceptions of value-in-use evolve over time. Despite the less than positive evaluations described at Year 4, the contract was renewed into Year 5.

Place Table 1 Here

Place Table 2 Here

Place Figure 2 Here 


\section{Discussion}

Our analysis of customer perceptions of quality and value shows that customers can - independently and without prompting - articulate their quality perceptions of provider processes. In the case study, customers articulated dimensions of service quality (including at the provider organization and individual SP level) and relationship quality (again at the levels of organization and individual). Additionally, our research indicates that customers can provide an assessment of the quality of their own usage processes (discussed below). Furthermore, our research indicates that customers can articulate the value-in-use derived in terms of goal-related constructs (also discussed below).

An emergent theme was that customers assess the network quality of the provider: that is, the provider's strength in accessing and making use of other suppliers. In this manner, the provider acts not only as a resource provider to the customer but also as a resource integrator (McColl-Kennedy et al., 2009). If customers, too, are resource integrators, one of the tasks they can choose to outsource is some of this resource integration. The customer's decision to sign up the provider in this case thus involved redrawing much of the customer's network (Gummesson, 2006; Normann \& Ramirez, 1993). This echoes Vargo, et al.'s (2008: 149) coining of the term 'value-in-context', which they discuss as: "improvement in system well-being and we can measure value in terms of a system's adaptiveness or ability to fit in its environment". While we define value-in-use in terms of the customer's goals, purposes or objectives, it arises from a variety of resources within the customer's network, or the system within which the customer resides, including not just those 
directly provided by the provider and the customer but also those provided by other actors in a configuration which the provider-customer relationship may influence.

Based on our conceptualization and the findings from this exploratory study, we make four key propositions in the subsections which follow.

\subsection{The need for new quality measures}

Despite Woodruff's (1997: 149) identification of the need for companies wanting to "compete...on superior customer value delivery" to improve their "customer learning and translation processes [as a] core competency issue", and the increasingly widespread discussion of the contention that value is created "in use" (Vargo \& Lusch, 2006, 2008a), the predominant measures of quality continue to ignore co-creation processes. For instance, none of the five SERVQUAL dimensions of tangibility, reliability, responsiveness, assurance or empathy relates to customer co-created value (Parasuraman, et al., 1988). Performance measures play a key role in organizational learning (Sinkula, Baker \& Noordewier, 1997). Assessment of customer co-created value is a potentially vital performance measure for the provider, for whom it may influence service design. Equally, for the customer, it may assist with 'outsource versus in-house' decisions, with monitoring the provider, and with negotiating terms. In Zeithaml's (1988) early conceptualization of quality, value mediated between quality and price on the one hand, and relationship outcomes on the other; despite this, the majority of service quality research in the intervening period has endeavoured to relate quality to relationship outcomes such as overall satisfaction and retention directly (DavisSramek, Droge, Mentzer \& Myers, 2009). As our conceptual framework makes clear, the omission of usage process quality and value-in-use from such models implicitly assumes that value is created at the moment of service delivery. This assumption is more explicit in the common notion of value as quality divided by price (Naumann, 2004) - a very different concept from Zeithaml's (1988) 
conception as quality and price as antecedents to value, which allows for the existence of other antecedents. While Naumann's equation might form a reasonable assessment of value-in-exchange (Vargo \& Lusch, 2004), it is far from a measure of value-in-use. Thus our first proposition is as follows:

Proposition 1: Current service quality measures, when used in isolation, assume that value is embedded at the moment of service delivery.

\subsection{Usage process quality}

Usage process quality does not previously appear to have been conceptualised or empirically examined in SDL, although there has been a somewhat related examination of user processes as part of the technology acceptance model (TAM) in the information systems literature (Davis, Bagozzi \& Warshaw, 1989). Satisfaction surveys assume that customers can assess the quality of provider processes. Yet our research shows that customers are quite capable of also articulating their perceptions of the quality of their own processes through interaction, usage, and engagement in their networks. Importantly, this spontaneous talk relates not just to the nature of the usage process but also to its perceived excellence or superiority - that is, its quality. As with assessments of service quality, customers elaborate on why certain features of the usage process are or are not regarded as excellent, in terms of the goals, purposes or objectives that are thereby aided or hindered. Hence our second proposition is that:

Proposition 2: The customer's usage processes can be subjected to quality assessment and related to value-in-use.

\subsection{The elicitation of value-in-use}


An important finding from our data is that - as with usage process quality - customers can and (provided not prompted by an excessively narrow question about the value 'delivered by' the provider) spontaneously do articulate their goals, purposes or objectives, the extent to which these are co-created with the provider, and the goal hierarchy by which this value-in-use derives from provider and customer process quality. This leads to our third proposition:

\section{Proposition 3: Value-in-use can be articulated by the customer, just as customers can articulate service quality.}

We note that this proposition, in conjunction with Propositions 1 and 2, adds support to Vargo and Lusch's $(2004,2008 \mathrm{~b})$ definition of service as the provider's process of using its resources for the benefit of the customer. ${ }^{3}$ On the one hand, the customer integrates other resources too in order to achieve the benefits they seek: not least, through their own usage processes. Hence service is distinct from value-in-use. On the other hand, service is defined in terms of its contribution to those benefits; that is, the customer perceives a causal chain between the service provided and the benefits achieved; and, importantly, the customer judges quality precisely in terms of those service attributes which are hypothesized as contributing to the customer's objectives. Support for this argument from goal theory and from our B2B exploration suggests that these definitions of service quality and value-in-use are not just scholarly constructs but are indeed elicitable aspects of the customer's worldview.

This articulation of value-in-use is at both an individual level and a corporate one. Not surprisingly, corporate level evaluations of value-in-use were predominantly made by decision makers, while users tended to assess value-in-use at an individual level. This is consistent with other laddering

\footnotetext{
${ }^{3}$ We thank an anonymous reviewer for this insight.
} 
studies which observe that decision makers move more quickly to organizational benefits than those lower down in the organization hierarchy (Rugg et al., 2002). This might appear to lend support to previous research which has focused on understanding management perceptions of value.

However, an important finding is that value-in-use assessment at both levels is important to the customer organization's aggregate view of value. This was emphasised by observations that: (a) all of the managers said that following the initial implementation of the OMS, their assessment of value had been formed by observing the impact on the factory floor (i.e. their perceptions of the impact on users); and (b) one manager emphasised that as a general rule, he made his assessments only after seeking input from factory floor supervisors (i.e. the users).

\subsection{The evolution of value-in-use}

Value-in-use changes by definition depending on the customer's goals. Customers of B2B solutions may be motivated by 'promotion goals', such that the value of a solution might arise from its ability to increase the productivity or effectiveness of the organization. Solution selling often relies on identifying the performance-related objectives of the customer. However, customers of solutions may be even more strongly motivated by 'prevention goals', where the competitive context "makes addressing specific painful problems unmistakably urgent” (Lay, Hewlin \& Moore, 2009: 48).

That value-in-use changes over time became clear from the case study (consistent with the work of Beverland and Lockshin, 2003). Customers' goals change at different stages of the relationship and affect their evaluations of value. Activities that might have initially led to high levels of satisfaction may later be considered 'just a given' at subsequent stages of the relationship. Our reading of the case data interprets the changes in value-in-use sought as due, at least in part, to shifts in corporate and individual goals from preventative to promotional (see Section 5.5, and in particular contrast Figure 2 with Figure 3). 
We note, however, that alternative or complementary interpretations of the data are possible. For example, by Year 4, perhaps easier tasks had been solved and remaining tasks were more difficult, giving the provider increased difficulty in satisfying the customer. Or alternatively, by Year 4 the customer may have changed their value assessment because they had seen the problem solved, recognised the superiority of this alternative way of operating, and adopted it. Hence adoption of innovations may provide an alternative lens for viewing the evolution of the service, and the assessments applied to it, over time. In any event, our case data may not prove typical of other contexts. We therefore tentatively offer the following proposition, with the caveat that it requires further empirical exploration.

\section{Proposition 4: The value-in-use sought tends to shift from preventative goals to promotional goals as the former are satisfied.}

This echoes consumer research on the relationship between benefits and post-consumption feelings. Given that avoiding pain is a necessity and that seeking pleasure is a relative luxury, customers initially give higher priority to utilitarian benefits than to hedonic benefits (Chitturi, Raghunathan \& Mahajan, 2008: 50). This means that customers seek to initially "eliminate the points of pain" (Keiningham \& Vavra, 2001: 176) by meeting prevention goals (such as confidence and security) through utilitarian benefits. However, once prevention goals are met, customers tend to "then listen to their desires" (Keiningham \& Vavra, 2001: 176). At this point the provider's focus should be on customer delight which is not directly influenced by either prevention emotions or by satisfaction. The provider should be focusing on the promotion benefits that will lead to feelings of excitement and cheerfulness. 


\section{Conclusions}

Our conceptual framework for assessment of value-in-use implies that customer value may be unearthed by examining the interconnected constructs of: (a) customer assessment of service quality, relationship quality, and the emergent construct of network quality; (b) customer assessment of usage process quality; and (c) value-in-use. The case data were consistent with this framework, while adding a new construct, network quality.

The framework views value-in-use as multi-dimensional, and acknowledges both provider and customer contributions to value creation. It provides deeper insight than service quality alone by considering directly the customer's goals. This link to goals acknowledges that value-in-use may have individual components within the corporate environment: as our data show, decision-making units are made up of value-seeking individuals, who perceive the achievement of individual goals as well as corporate ones.

Our interviews with the customer and the provider have shown that both have a strong interest in understanding customer-perceived value. Both sides are dissatisfied with existing measures. We suggest that by surfacing usage process quality and the value-in-use - and not just service quality which practitioners, like scholars, currently tend to focus on - we can give both sides much greater clarity on customer perceived value. For the provider this has implications for crafting, communicating and delivering value propositions. For the customer this clarity may assist in assessing the cost-benefit trade-off for propositions such as outsourced maintenance. A further application is that by articulating usage process quality and value-in-use, both parties will be in a better position to determine how their continuing dialogue might generate value in new ways (Ballantyne \& Varey, 2006b). 
As Vargo and Lusch (2004) have argued and our data make plain, value-in-use is highly context specific. Although service quality has many commonalities across contexts, the same seems unlikely to be the case - at least to the same extent - with value-in-use. Each context, therefore, is likely to require qualitative exploration in the first instance. Our study suggests that this is perfectly feasible, and provides in particular the insight that in a B2B context multiple respondents are needed in order to assess value-in-use at individual as well as organizational level; studies in other contexts - with different sectors, marketing practice archetypes and so on - are needed. There seems to be no reason why such qualitative work should not be followed by quantitative assessment of value perceptions, their antecedents such as the quality of service, relationships, networks and usage processes, and their consequences. This would go some way to answering Woodruff's (1997) call over a decade ago for "new method tools ... to deal with particular customer value learning issues, such as predicting customer value change" (Woodruff 1997: 150).

\subsection{Managerial implications}

We contribute to a key research priority for managers (Ostrom et al., 2010) by proposing a new framework for value-in-use assessment. The conceptual framework shows how customers construe the perceived value of service, and suggests that methods that can uncover the multiple aspects of quality and their connection to value-in-use will be required as a precursor to developing quantitative methods for assessing value-in-use. Notably, we suggest that qualitative methods incorporating laddering will indeed be needed (unless this insight is available informally as a sideeffect of relational contact) before survey methods can be used, in order to tease out the dimensions of value-in-use, usage process quality and so on. A regular customer satisfaction tracker could then be extended to include not just satisfaction with the provider's service but also with the firm's own usage processes, as well as value-in-use perceptions. 
Such holistic measures of value-in-use and its antecedents would have multiple purposes. First, for important customers such as key accounts, customer-specific problems and opportunities could be identified. Second, aggregate data could be used for purposes of management control. Third, cluster analysis could be used to identify commonalities and differences in value-in-use perceptions. The provider in our case study indeed intends to develop such a customer survey based on the qualitative work reported in this paper.

The case also provides a commentary on the advantages and pitfalls that can arise from managers achieving one of their key research priorities (Ostrom et al., 2010): to stimulate service innovation. The innovation in this case was a complex proposition which evolved as the customer's goals changed. The embodiment of the proposition in this case as an on-going business relationship implies possibilities for further developing it after its initial implementation through modifications, upgrades and cross-selling. This was evident where the customer was calling for more innovation as the relationship continued, calls which the provider did not always heed. Partly because it had allowed its embedded SP (who worked mostly at the operational level) to take over communication, the provider's relationship with the customer had shifted down from a strategic relationship to an operational one. The danger of no longer holding that conversation at managerial level with the customer meant that had it not addressed this issue, the provider might have missed key opportunities to protect and continue to enhance the relationship. One challenge, then, to innovating providers appears to be to make the value-in-use currently being perceived by operational level staff in the customer organization visible to the decision-making unit.

\subsection{Limitations and directions for future research}

The service evaluated in this case study is tailored to the customer, and the mechanisms identified as being key in the case may be specific to the context. While the challenge to assess customer- 
perceived value that faced both customer and provider in this case may prove typical where business models are in flux, future research might beneficially apply the conceptual framework in other contexts.

Such work might also help towards scale development for usage process quality, network quality and value-in-use, along the lines of service quality scales. We note, however, that significant context specificity may be found for value-in-use in particular. While this is not necessarily a problem for practitioners, who can use an initial qualitative study within a specific context prior to survey design, scholarly research may wish to explore whether generalised scales can be developed. Survey work might also form the basis for exploration of variations in value propositions across members of the buying group.

Finally, the time element in this study emerged from the depth interviews as a result of the interviewees' own identification of distinct time periods over which value-in-use varied. As suggested by Quintens and Matthyssens (2010), future researchers may wish to explicitly track value creation over time. 


\section{REFERENCES}

Anderson, J.C. \& Narus, J.A. (1998). Business marketing: Understand what customers value. Harvard Business Review, 76 (Nov-Dec), 53-65.

ANSI/ASQC (1987) Quality Systems Terminology, American National Standard A3-1987.

Arnould, E.J., Price, L.L., \& Malshe, A. (2006). Towards a cultural resource-based theory of the customer. In R.F. Lusch \& S.L. Vargo (Eds.), The service-dominant logic of marketing: dialog, debate, and directions. Sharpe, New York.

Bagozzi, R. P. (1997). Goal-directed behaviours in marketing: Cognitive and emotional perspectives. Psychology \& Marketing, 14 (6), 539-543.

Baines, T., Lightfoot, H., Evans, S., Neely, A., Greenough, R., Peppard, J., Roy, R., Shehab, E., Braganza, A., Tiwari, A., Alcock, J., Angus, J., Bastl, M., Cousens, A., Irving, P., Johnson, M., Kingston, J., Lockett, H., Martinez, V., Michele, P., Tranfield, D., Walton, I.M., \& Wilson, H.N. (2007). State-of-the-art in product-service systems. Proceedings of the Institution of Mechanical Engineers, Part B: Journal of Engineering Manufacture, 221 (10), 1543-1552.

Ballantyne, D. \& Varey, R. J. (2006a). Creating value-in-use through marketing interaction: the exchange logic of relating, communicating and knowing. Marketing Theory, 6 (3), 335.

Ballantyne, D. \& Varey, R. J. (2006b). Introducing a dialogical orientation to the service-dominant logic of marketing, in The service-dominant logic of marketing: dialog, debate, and directions. In R.F. Lusch \& S.L. Vargo, eds., Sharpe, New York.

Beverland, M. \& Lindgreen, A. (2010). What makes a good case study?: A positivist review of qualitative case research published in Industrial Marketing Management, 1971-2006, Industrial Marketing Management, 39, 56-63.

Beverland, M.B. \& Lockshin, L.S. (2003). A longitudinal study of customers' desired value change in business-to-business markets. Industrial Marketing Management, 31 (8), 653-666.

Botschen, G., Thelen, E.M. \& Pieters, R. (1999). Using means-end structures for benefit segmentation: An application to services, European Journal of Marketing, 33 (1/2), 38-58. 
Buttle, F. (1996). SERVQUAL: Review, critique, research agenda. European Journal of Marketing, $30(1), 8-32$.

Cassel, C. \& Symon, G. (1990). Qualitative methods in organizational research. Sage Publications: London.

Chitturi, R., Raghunathan, R. \& Mahajan, V. (2008). Delight by design: The role of hedonic versus utilitarian benefits. Journal of Marketing, 72 (May), 48-63.

Crosby, L.A., Evans, K.R. \& Cowles, D. (1990). Relationship quality in services selling: An interpersonal influence perspective. Journal of Marketing, 54 (July), 68-81.

Davis, F.D., Bagozzi, R.P. \& Warshaw, P.R. (1989). User acceptance of computer technology: A comparison of two theoretical models. Management Science, 35 (8), 982-1003.

Davis-Sramek, B., Droge, C., Mentzer, J.T. \& Myers, M.B. (2009). Creating commitment and loyalty behavior among retailers: What are the roles of service quality and satisfaction? Journal of the Academy of Marketing Science, 37, 440-454.

Deeter-Schmelz, D. R., Kennedy, K. N., \& Goebel, D. J. (2002). Understanding sales manager effectiveness-linking attributes to sales force values. Industrial Marketing Management, 31, $617-626$.

Diamond, N., Sherry, J.F. Jr., Muniz, A.M. Jr., McGrath, M.A., Kozinets, R.V. \& Borghini, S. (2009). American Girl and the brand gestalt: Closing the loop on sociocultural branding research. Journal of Marketing, 73 (May), 118-134.

Dorsch, M.J., Carlson, L., Raymond, M.A. \& Ranson, R. (2001). Customer equity management and strategic choices for sales managers. Journal of Personal Selling and Sales Management, 21 (2), 157-166. 
Dorsch, M.J., Swanson, S.R. \& Kelley, S.W. (1998). The role of relationship quality in the stratification of vendors as perceived by customers. Journal of the Academy of Marketing Science, $26(2), 128-142$.

Easton, G. (2010). Critical realism in case study research. Industrial Marketing Management, 39, $118-128$

Evanschitzky, H., v. Wangenheim, F., \& Woisetschläger, D. (2011). Introduction to the Special Issue on Service \& Solution Innovation. Industrial Marketing Management, this issue.

Flint, D.J. \& Mentzer, J.T. (2006). Striving for integrated value chain management given a service dominant logic for marketing, in The service-dominant logic of marketing: dialog, debate, and directions, R.F. Lusch \& S.L. Vargo, eds., Sharpe, New York.

Guenzi, P. \& Troilo, G. (2006). Developing marketing capabilities for customer value creation through Marketing-Sales integration. Industrial Marketing Management, 35, 974-988.

Gummesson, E. (1995). Relationship marketing: Its role in the service economy, in Understanding Services Management, W.J. Glynn \& J.G. Barnes, eds., Wiley, New York.

Gummesson, E. (2006). Many-to-many marketing as grand theory: A Nordic school contribution, in The service-dominant logic of marketing: dialog, debate, and directions, R.F. Lusch \& S.L. Vargo, eds., Sharpe, New York.

Gutman, J. (1997). Means-end chains as goal hierarchies. Psychology \& Marketing, 14 (6), 545560.

Gutman, J. (1982). A means-end chain model based on consumer categorization processes. Journal of Marketing, 46 (2), 60-72.

Haase, M. \& Kleinaltenkamp, M. (2011). Property rights design and market process: Implications for market theory, marketing theory, and S-D Logic. Journal of Macromarketing, forthcoming. DOI: $10.1177 / 0276146710397662$. 
Huff, A.S. (1990). Mapping strategic thought. John Wiley, Chichester.

Jacob, F. \& Ulaga, W. (2008). The transition from product to service in business markets: An agenda for academic inquiry. Industrial Marketing Management, 37 (3), 247-253.

Johnston, W.J., Leach, M.P. \& Liu, A.H. (1999). Theory testing using case studies in business-tobusiness research. Industrial Marketing Management, 28, 201-213.

Judd, D.K. (1994), The psychology of quality, American Society for Quality Control, $48^{\text {th }}$ Annual Quality Congress Proceedings, 134-139.

Keiningham, T., \& Vavra, T. (2001). The customer delight principle: Exceeding customers' expectations for bottom-line success. McGraw Hill, New York.

Kelly, G.A. (1963). A theory of personality: The psychology of personal constructs. Norton, New York.

Kettinger, W.J., \& Lee, C.C. (1994). Perceived service quality and user satisfaction with the information services function. Decision Sciences, 25 (5/6), 737-766.

Langfield-Smith, K. (1992). Exploring the need for a shared cognitive map. Journal of Management Studies, 29, 349-367.

Larson, J.R. Jr. \& Christensen, C. (1993). Groups as problem-solving units: Toward a new meaning of social cognition. British Journal of Social Psychology, 32, 5-30.

Lay, P., Hewlin, T. \& Moore, G. (2009). In a downturn, provoke your customers. Harvard Business Review, March, 48 - 56.

Lindgreen, A \& Wynstra, F. (2005). Value in business markets: What do we know? Where are we going? Industrial Marketing Management, 34, 732-748.

Locke, E.A. \& Latham, G.P. (2002). Building a practically useful theory of goal setting and task motivation: A 35 year odyssey. American Psychologist, 57 (9), 705-717. 
Lusch, R.F. Vargo, S.L. \& O’Brien, M. (2007). Competing through service: Insights from servicedominant logic. Journal of Retailing, 83 (1), 5-18.

Kirmani, A. \& Rao, A.R. (2000). No pain, no gain: A critical review of the literature on signaling unobservable product quality. Journal of Marketing, 64 (Apr), 66-79.

Morgan, R.M. \& Hunt, S.D. (1994). The commitment-trust theory of relationship marketing. Journal of Marketing, 58 (July), 20-38.

McColl-Kennedy, J., Vargo, S.L., Dagger, T. \& Sweeney, J. (2009). Customers as resource integrators: Styles of customer co-creation. Performance Measurement Association Conference, University of Otago, New Zealand, April 2009. Available at: www.pma.otago.ac.nz/pma-cd/papers/ (accessed 17-May-2009).

Moller, K. (2006). Role of competencies in creating customer value: A value-creation logic. Industrial Marketing Management, 35, 913-924.

Naumann, E. (2004). Creating customer value: The path to sustainable competitive advantage. Thomson, New York.

Normann, R. \& Ramirez, R. (1993). From value chain to value constellation: Designing interactive strategy. Harvard Business Review, July-August, 65-77.

Neely, A. (2008). Exploring the financial consequences of the servitization of manufacturing. Operations Management Review, 1 (2), 103-118.

Ngo, L.V. \& O’Cass, A. (2009). Creating value offerings via operant resource-based capabilities, Industrial Marketing Management, 38, 45-59.

Ostrom, A.L., Bitner, M.J., Brown, S. W., Burkhard, K.A., Goul, M., Smith-Daniels, V., Demirkan, H. \& Rabinovich, E. (2010). Moving forward and making a difference: Research priorities for the science of service, Journal of Service Research, 13 (4), 4-36. 
Parasuraman, A., Zeithaml, V. \& Berry, L. (1988). A conceptual model of service quality and its implications for future research. Journal of Marketing, 49 (Fall), 41-50.

Paulssen, M. \& Bagozzi, R.P. (2006). Goal hierarchies as antecedents of market structure. Psychology \& Marketing, 23 (8), 689-709.

Payne, A.F., Storbacka, K. \& Frow, P. (2008). Managing the co-creation of value. Journal of the Academy of Marketing Science, 36, 83-96.

Peterman, M.L. (1997). The effects of concrete and abstract consumer goals on information processing. Psychology \& Marketing, 14 (6), 561-583.

Prahalad, C.K. \& Ramaswamy, V. (2004). Co-creation experiences: The next practice in value creation. Journal of Interactive Marketing, 18 (3), 5-14.

Qualls, W.J. \& Rosa, J.A. (1995). Assessing industrial buyers' perceptions of quality and their effects on satisfaction. Industrial Marketing Management, 24, 359-368.

Quintens, L. \& Matthyssens, P. (2010). Involving the process dimensions of time in case-based research. Industrial Marketing Management, 39 (1), 91-99.

Rugg, G. E. M., Mahmood, A., Rehman, N., Andrews, S., \& Davies, S. (2002). Eliciting information about organizational culture via laddering. Information Systems Journal, 12, 215-229.

Schembri, S. (2009) Reframing brand experience: The experiential meaning of Harley-Davidson. Journal of Business Research, 62 (12), 1299-1310.

Sinkula, J.M., Baker, W.E. \& Noordewier, T. (1997). A framework for market-based organizational learning: Linking values, knowledge, and behaviour. Journal of the Academy of Marketing Science, 25 (4), 305-319.

Stake, R.E. (1995). The art of case study research. Sage Publications: Thousand Oaks, California. 
Storbacka, K., Strandvik, T. \& Gronroos, C. (1994). Managing customer relationships for profit: The dynamics of relationship quality. International Journal of Service Industry Management, 5 (5), 21-38.

Trist, E. (1983). Referent organizations and the development of inter-organizational domains. Human Relations, 36 (3), 269-284.

Tukker, A. \& Tischner, U. (2006). New business for the old Europe: Product-service development, competitiveness and sustainability. Greenleaf Publishing: Sheffield, UK.

Tuli, K., Kohli, A. \& Bharadwaj, S. (2007). Rethinking customer solutions: From product bundles to relational processes. Journal of Marketing, 71 (July), 1-17.

Ulaga, W. (2003). Capturing value creation in business relationships: A customer perspective. Industrial Marketing Management, 32, 677-693.

Ulaga, W. \& Eggert, A. (2006). Relationship value and relationship quality. European Journal of Marketing, 40 (3/4), 311-327.

Van der Haar, J.W., Kemp R.G.M. \& Omta, O. (2001). Creating value that cannot be copied. Industrial Marketing Management, 30, 627-636.

Vandermerwe, S. \& Rada, J. (1988). Servitization of business: Adding value by adding services. European Management Journal, 6 (4), 314-324.

Vargo, S.L. \& Lusch, R.F. (2004). Evolving to a new dominant logic for marketing. Journal of Marketing, 68 (Jan), 1-17.

Vargo, S.L. \& Lusch, R.F. (2006). Service-dominant logic: What it is, what it is not, what it might be, in The service-dominant logic of marketing: dialog, debate, and directions, R.F. Lusch \& S.L. Vargo, eds., Sharpe, New York.

Vargo, S.L. \& Lusch, R.F. (2008a). Service-dominant logic: Continuing the evolution. Journal of the Academy of Marketing Science, 36, 1-10. 
Vargo, S.L. \& Lusch, R.F. (2008b). From goods to service(s): Divergences and convergences of logics. Industrial Marketing Management, 37 (3), 254-259.

Vargo, S.L., Lusch, R.F. \& Morgan, F.W. (2006). Historical perspectives on service-dominant logic, in The service-dominant logic of marketing: dialog, debate, and directions, R.F. Lusch \& S.L. Vargo, eds., Sharpe, New York.

Vargo, S.L., Maglio, P.P., \& Akaka, M.A. (2008). On value and value co-creation: A service systems and service logic perspective. European Management Journal, 26, 145-152.

Walter, A., Ritter, T. \& Gemunden, H.G. (2001). Value creation in buyer-seller relationships:

Theoretical considerations and empirical results from a supplier's perspective, Industrial Marketing Management, 30, 365-377.

Woodruff, R.B. (1997). Customer value: The next source for competitive advantage. Journal of the Academy of Marketing Science, 25 (2), 139-153.

Woodruff, R.B. \& Flint, D.J. (2006). Marketing's service-dominant logic and customer value, in The service-dominant logic of marketing: dialog, debate, and directions, R.F. Lusch \& S.L. Vargo, eds., Sharpe, New York.

Woodruff, R.B. \& Gardial, S.F. (1996). Know your customer: New approaches to understanding value and satisfaction. Blackwell, Cambridge.

Woodside, A.G. (2010), Bridging the chasm between survey and case study research: Research methods for achieving generalization, accuracy and complexity, Industrial Marketing Management, 39, 64-75.

Zeithaml, V.A. (1988). Consumer perceptions of price, quality, and value: A means-end model and synthesis of evidence. Journal of Marketing, 52 (3), 2-22.

Zeithaml, V., Berry, L. \& Parasuraman, A. (1996). The behavioral consequences of service quality. Journal of Marketing, 60 (April), 31-46. 
Table 1: Quality and value dimensions (Year 1)

\section{Dimensions \\ Interview(s) Illustrative quotation(s)}

\section{SERVICE QUALITY}

\section{Organization}

Warranty maximisation

Inventory management and sourcing obsolete

items

Supplier management

U3, D5. D7, D4 "A huge bonus because we may leave some of the spare parts we have in our stores for two years before we ever need them" (D5)

D4, D6, D7 "They drive value through better management of inventory" (D4). "They found us obsolete parts overseas and had them shipped over. We can't find things like that" (D7).

Responsiveness

$\mathrm{U} 1, \mathrm{U} 2, \mathrm{U} 3$,

D5, D7

"They are very good at getting a new supplier into their system very quickly" (U1). "They will use the same supplier that we do but all the negotiation side of it is done by them rather than myself which saves me days" (U2)

D4 "Responsiveness depends on the individual service professional. There is a bit of a learning curve for a new provider" (D4)

\section{Service professional}

Commitment

D5 "He worked daft hours" (D5)

Competence / experience

\section{RELATIONSHIP QUALITY}

\section{Organization}

Organizational closeness

The supplier's management team "were on site, they were contacting us, asking Are you happy as a customer? and that was great, a great relationship" (D8). "We have a working relationship through the contracts" (D6)

Trust

Mutual benefit

"I have a lot of trust in their processes because they made a difference so quickly" (D7)

\section{Service professional}

Personal appea

D5 "A great guy" (D5)

Interpersonal relationship

D4, D5, D7

\section{NETWORK QUALITY}

Buying power

Supplier coordination
"A great relationship with him" (D4); "He works closely with us at senior level" (D5); "He has been very good at building relationships with us and with trust you get good information flows" (D4) 
Table 1: Quality and value dimensions (Year 1) (cont.)

\section{Dimensions Interview(s) Illustrative quotation(s)}

\section{CUSTOMER USAGE PROCESS QUALITY}

Input time

Conforming to process

User contribution

Proximity \& Intimacy
U1, U2, U3, D7

U3

D7

D7

"All the engineer does is give the broken bit...to the service professional and he will organise to get it fixed" (D7).

"Now it's just ten minutes in the [drop-off] area, and then I can say 'Get on with it, it's your job now, I've got something else to do" (U3).

"It's a 2-way street with equipment suppliers. We need to maintain the machines well if we want to help us" (D7).

"I told my guys: Here's the deal, I will purchase my team new stock on condition that you agree to label and store it properly". (D7)

"I treated the service professional as part of my team, I didn't treat him as a service provider. He sat in the same office with my first line and every day he spoke to them...He came to our team meetings; he was part of my extended team" (D7)

\section{VALUE IN USE}

\section{To the organization}

\section{Efficiency}

Asset maximisation

Asset control

Time for core business

\section{To the individual}

Time for my real job

Transfer the problem

Risk management
"One line that previously was at $35 \%$ operating efficiency is now at $85 \%$ operating efficiency" (D7)

"The value can be seen in the supply of major components to schedule, on time and to the quality standards expected" (D5). "We found \$1M in obsolete stock and \$2M equipment in various stores" (D5)

"It was introduced to get control over our stores and planning" (D6)

"It gave the technical coordinators more time. They could get out of their offices, they could start talking to the maintenance guys. It was like, I guess, a snowball effect" (D7). "We'd probably taken our eye off what supervisors should predominantly be doing which is preventative stuff, the visionary stuff, trying to do the planning, the preparation and delivering projects" (U8)

$\mathrm{U} 1, \mathrm{U} 2, \mathrm{U} 3$

D5, D7, U8

U1, U2, U3, U8 "It frees up my time" (U1); "It saves days in negotiation" (U1), "I save days chasing parts" (U3)

U1, U2, U3

"It makes my life easy because I just say, there you are [provider] sort it out for me and then it's not my problem anymore" (U1) "Gets rid of my red tape activities" (U2)

"If a repair doesn't come back right I can blame [the provider]" (U1) 
Table 2: Quality and value dimensions (Year 4)

\section{Dimensions Interview(s) Illustrative quotation(s)}

\section{SERVICE QUALITY}

\section{Organization}

Reporting on warranty

"They don't give us reports on warranty repairs anymore" (D5)

Reporting on repairs

\section{Quality of repairs}

Customer focus

"Of the ones that failed what did they do? I want them to show me how they are consistently improving" (D6). "We should get sent a report on the items that were sent away" (U8). "We want not a lot of hassle to find out what has been done" (U3).

"There's a problem - which I'm surprised they've got - we aren't sure of the quality of their repairs" (U3). "But a problem we are seeing a lot of, which then causes my guys more work, is things coming back that aren't repaired" (U2).

"The problem is that they are constantly looking at their bottom line, not at our bottom line" (D6).

\section{Service professional}

Sense of urgency

"I think they often don't understand what I mean by urgent.. when I say something is urgent I expect a courier now to get the part and take it away" (U1)

Competence / experience D5, U8

"They lack someone with the knowledge of [the original service professional]... we've had some real sagas" (D5).

\section{RELATIONSHIP QUALITY}

Communication

D5, D6, D7

Closeness of

management teams

Nature of relationship
"As a service provider, I think they should be doing a better job at telling us what they are doing for us rather than us asking them" (D7). "They should provide more quantitative measures of the services they offer (for example the percentage of people who are satisfied" (D6). "I've got problems with the transparency on the reporting and things" (D5).

"We never see their management team anymore" (U8).

"The current relationship is OK but not great" (D6)

\section{NETWORK QUALITY}

"I just get the feeling that [the provider] hasn't got the breadth of suppliers they need to have" (D5) 
Table 2: Quality and value dimensions (Year 4) (cont.)

\section{Dimensions Interview(s) Illustrative quotation(s)}

\section{CUSTOMER USAGE PROCESS QUALITY}

Micro-management (-ve) U1, U8

Regular analysis

D4, D7

Communication channel

D5

Sharing customer

information
"We often have to chase stuff up with them which I don't want to do" (U1). "We are having to audit them because we don't have the confidence they are doing it" (U8)

"I think we have lost our way a bit in terms of the quantitative analysis" (of the value of the service) (D7). "We don't do audits any more, we are just letting them get on with it. And they cynical people would say they are ripping us off" (D7). "We need to make a competitiveness check" (D4)

"There's confusion now about the process...things are getting lost, things are taking longer...the communication channels are longer and you inevitably get Chinese whispers" (D5).

"We are not good at sharing information effectively with [the provider]. A lot of the information that we have is not useful for them and makes forward forecasting difficult for them" (D4).

\section{VALUE IN USE}

\section{To the organization}

Continuity of operation

Retention of knowledge

Retention of competency

Security

"In the last year we haven't stopped the track once" (D5)

"In the three odd years we've lost track of how much these repairs would cost us in the open market" (D5)

"It was becoming very easy...we weren't doing stuff we were trained to do...so obviously there's on costs with that , so now we are trying to repair a lot more stuff ourselves" (U2)

"I am concerned that having incorrect parts could mean potentially a stop on a line, because even something quite small could stop a line" (U8)

"When things come back unrepaired they cause my guys more work" (U2). 
Figure 1: Conceptual framework for customer assessment of value-in-use

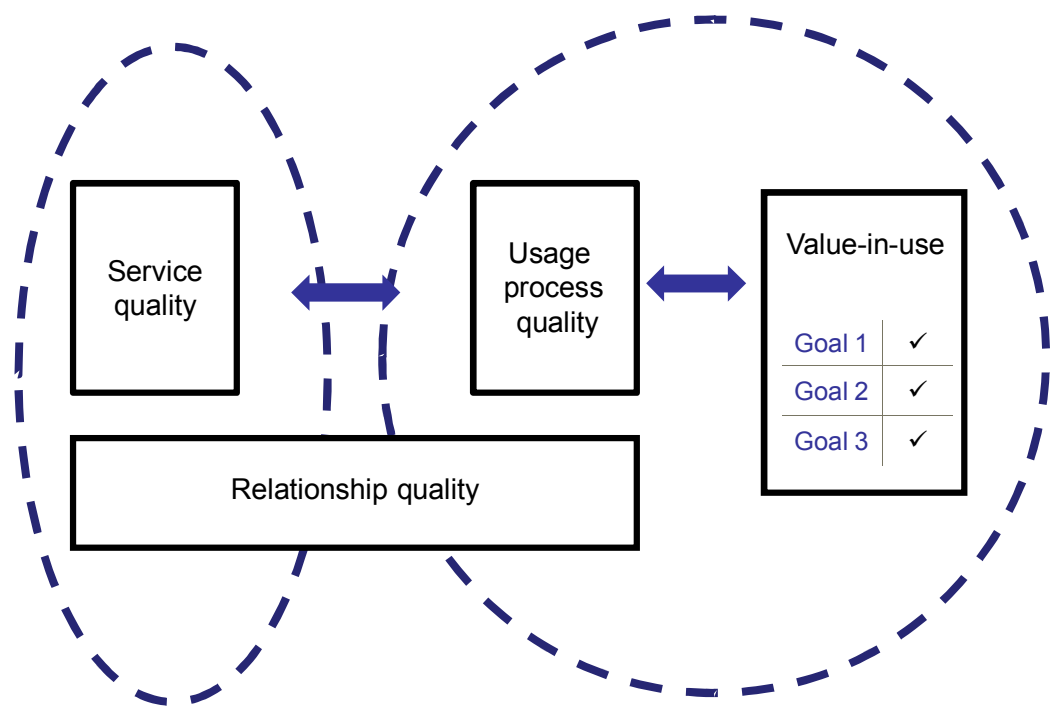

Provider processes

Customer processes 
Figure 2: Customer perceptions of quality and value (Year 1)

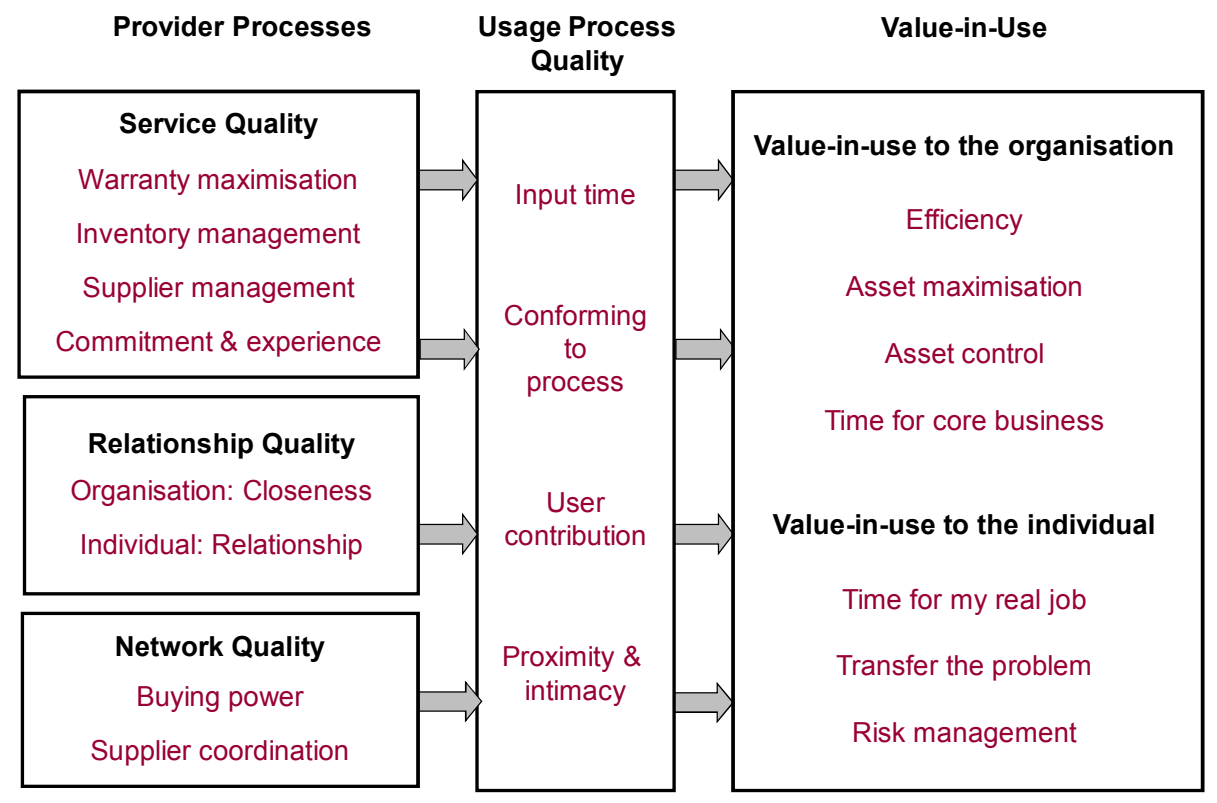


Figure 3: Customer perceptions of quality and value (Year 4)

\begin{tabular}{|c|c|c|}
\hline Provider Processes & $\begin{array}{c}\text { Usage Process } \\
\text { Quality }\end{array}$ & Value-in-Use \\
\hline $\begin{array}{c}\text { Service Quality } \\
\text { Reporting on warranty } \\
\text { maximisation } \\
\text { Reporting \& quality of repairs } \\
\text { Sense of urgency }\end{array}$ & $\begin{array}{c}\begin{array}{c}\text { Regular } \\
\text { analysis }\end{array} \\
\text { Communication } \\
\text { channel }\end{array}$ & $\begin{array}{l}\text { Value-in-use to the organisation } \\
\text { Continuity of operation } \\
\text { Retention of knowledge }\end{array}$ \\
\hline $\begin{array}{c}\text { Relationship Quality } \\
\text { Communication } \\
\text { Closeness of management teams }\end{array}$ & $\begin{array}{l}\text { Sharing } \\
\text { customer } \\
\text { Information }\end{array}$ & $\begin{array}{l}\text { Retention of competencies } \\
\text { Security }\end{array}$ \\
\hline $\begin{array}{l}\text { Network Quality } \\
\text { Coverage of } \\
\text { supplier networks }\end{array}$ & $\begin{array}{l}\text { Micro- } \\
\text { management } \\
(-\mathrm{ve})\end{array}$ & Time \\
\hline
\end{tabular}

